\title{
Kandungan Zat Besi pada Produk Makanan Bayi Siap Saji
}

\author{
Titis Prawitasari \\ Departemen Ilmu Kesehatan Anak Fakultas Kedokteran Universitas Indonesia RS Cipto Mangunkusumo, \\ Jakarta
}

\begin{abstract}
Latar belakang. Setelah ASI eksklusif 6 bulan, bayi harus telah mendapatkan MPASI karena cadangan zat besi dalam tubuh yang makin menipis dan asupan yang diperoleh dari ASI sudah tidak memadai lagi.

Tujuan. Melakukan evaluasi kandungan zat besi yang tercantum dalam label produk MPASI siap saji yang ada di pasaran.

Metode. Dilakukan survei terhadap produk MPASI yang terdapat di swalayan di Jakarta Barat dan Timur selama bulan Mei 2011.

Hasil. Dievaluasi 15 produk dari 5 produsen, berupa bubur, tim dan biskuit untuk golongan usia 6 bulan ke atas, 8 bulan ke atas, dan 9 bulan ke atas. Semua mencantumkan petunjuk penggunaan dan saran penyajian. Takaran saji berbagai produk tersebut berbeda, antara 40-50 g (5-6) sendok makan per saji untuk bubur dan tim serta 19-21 g per saji (2-3) keping untuk biskuit. Jumlah kalori per saji MPASI bubur dan tim antara 160-210 kalori, sedangkan jumlah kalori per saji MPASI biskuit antara 80-90 kalori. MPASI yang terdapat di pasaran mempunyai kandungan zat besi berkisar antara 0,48-4,8 $\mathrm{mg}$ (6-60)\% dari AKG. Setelah 6 bulan, kekurangan asupan zat besi dapat tercukupi dengan minimal pemberian 1-2 kali MPASI siap saji per hari, di samping pemberian ASI atau susu formula sesuai kebutuhan berdasarkan usia.

Kesimpulan. Produk MPASI/makanan bayi siap saji yang ada di pasaran mengandung antara 0,48-4,8 mg zat besi per takaran sajinya. Produk MPASI biskuit mempunyai kandungan zat besi yang paling rendah di antara bentuk lainnya. Sari Pediatri 2012;14(4):265-8.
\end{abstract}

Kata kunci: makanan bayi, MPASI, zat besi

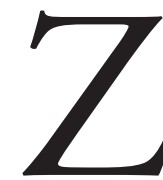

at besi merupakan salah satu zat mikronutrien yang sangat diperlukan oleh tubuh. Zat besi dibutuhkan oleh lebih dari 300 reaksi metabolisme dalam tubuh. ${ }^{1,2}$ Berbagai

\section{Alamat korespondensi:}

Dr. Titis Prawitasari, Sp.A. Divisi Nutrisi \& Penyakit Metabolik, Departemen Ilmu Kesehatan Anak, FKUI-RSCM. Jl. Salemba No.6, Jakarta 10430. Telp. (021) 3915715/3910096. E-mail: tprawitasari@ yahoo.com macam studi mengindikasikan bukti bahwa kadar zat besi yang rendah berhubungan dengan tingkat perkembangan kognitif yang lambat, motorik serta perkembangan sosial pada masa tumbuh kembang seorang anak. Beberapa keterlambatan perkembangan yang terjadi dapat diperbaiki setelah pemberian zat besi, tetapi pada defiensi zat besi yang telah terjadi sejak usia lebih dini sering bersifat permanen., ${ }^{3,4}$ Air susu ibu (ASI) merupakan sumber zat besi yang baik bagi bayi sebelum usia 6 bulan, tetapi setelah itu kadar 
zat besi dalam ASI sudah tidak memadai lagi untuk menunjang kebutuhan bayi. Oleh karena itu makanan pendamping ASI (MPASI) harus segera diberikan bagi bayi di atas 6 bulan, dan dipilih makanan yang banyak mengandung zat besi sehingga kebutuhan zat besi dapat tetap tercukupi dengan optimal. ${ }^{5}$ Pilihan MPASI yang diberikan dapat berupa makanan siap saji maupun buatan sendiri (home made). Studi kami mencoba melakukan survei terhadap produk MPASI/makanan bayi siap saji yang ada di pasaran dan melakukan kajian terhadap jumlah kandungan zat besi di dalamnya.

\section{Metode}

Dilakukan survei terhadap produk makanan bayi siap saji yang dijual di beberapa swalayan di Jakarta Timur dan Barat selama bulan Mei 2011. Produk makanan bayi siap saji yang dimaksudkan di sini adalah semua makanan bayi yang diberi label sebagai makanan pendampimg ASI untuk 6 bulan ke atas atau tertulis 6-24 bulan atau 8 bulan ke atas atau 9 bulan ke atas. Bentuknya dapat berupa bubur, biskuit maupun tim. Data diambil berdasarkan kadar atau nilai yang tercantum dalam informasi nilai gizi pada tiap kemasan produk. Dilakukan penyeragaman satuan untuk perhitungan zat besi menjadi milligram per satu takaran saji. Sebagai acuan kecukupan zat besi digunakan Angka kecukupan gizi (AKG) berdasarkan Widya Karya Pangan RI tahun 2004.

\section{Hasil}

Terkumpul 15 produk makanan bayi siap saji dari 5 produsen yang berbeda (Tabel 1). Jenis produk yang sama dengan rasa berbeda dari produsen yang sama diwakili oleh satu atau dua macam produk. Empat produsen mempunyai semua bentuk yang umum diberikan sebagai MPASI yaitu bubur, biskuit, dan tim. Hanya satu produsen yang produknya lebih sering ditemui dalam bentuk biskuit. Semua produsen mencantumkan label tulisan "Makanan Pendamping ASI Bubuk Instan" atau "Makanan Pendamping ASI Biskuit" dan menuliskan bentuk tekstur (bubur, tim atau biskuit) serta menuliskan usia peruntukkannya ( 6 bulan ke atas atau 6 bulan+ atau 6-24 bulan, 8 bulan ke atas atau 8 bulan+, $9 \mathrm{bln}+)$. Semua produsen juga mencantumkan petunjuk penggunaan dan saran penyajian. Takaran saji berbagai produk tersebut berbeda, tetapi berkisar antara 40-50 g (5-6 sendok makan) per saji untuk bubur dan tim dan 19-21 g

Tabel 1. Produk MPASI dan kandungan zat besi

\begin{tabular}{lcccc}
\hline Produk & $\begin{array}{c}\text { Takaran saji } \\
\text { (gram) }\end{array}$ & $\begin{array}{c}\text { Energi per saji } \\
\text { (kalori) }\end{array}$ & $\begin{array}{c}\text { Zat besi } \\
(\mathrm{mg})\end{array}$ & \%AKG \\
\hline Bubur/Tim 6 bulan ke atas & & & & \\
$\quad$ Cerelac beras merah & 50 & 210 & 4 & 50 \\
$\quad$ Cerelac beras putih & 50 & 210 & 3,6 & 45 \\
$\quad$ Cerelac tim ayam \& sayur & 50 & 200 & 3,6 & 45 \\
$\quad$ Milna cah daging kacang polong & 50 & 210 & 3,6 & 45 \\
$\quad$ Promina beras merah & 40 & 160 & 4,4 & 55 \\
$\quad$ SUN beras merah & 40 & 160 & 4 & 50 \\
$\quad$ SUN sari buah & 40 & 160 & 4 & 50 \\
Biskuit 6 bulan ke atas & & & & \\
$\quad$ Farley's rasa original & 20 & 80 & 0,48 & 6 \\
$\quad$ Milna rasa pisang & 21,8 & 90 & 2 & 25 \\
$\quad$ Promina rasa susu & 21 & 90 & 2 & 25 \\
$\quad$ SUN rasa jeruk & 19,29 & 80 & 2,4 & 30 \\
Bubur/Tim 8 bulan ke atas & & & & \\
$\quad$ Promina bubur mi & 25 & 110 & 2,4 & 30 \\
$\quad$ SUN tim instan ayam \& sayur & 25 & 100 & 2,4 & 30 \\
Bubur/tim 9 bulan ke atas & & & & \\
$\quad$ Cerelac coklat susu & 50 & 210 & 3,6 & 45 \\
$\quad$ Milna tumis hati ayam brokoli & 50 & 210 & 4,8 & 60 \\
\hline
\end{tabular}


Tabel 2. Angka kecukupan gizi (AKG)*

\begin{tabular}{lcc}
\hline Golongan usia & Energi (kalori) & Zat besi $(\mathrm{mg})$ \\
\hline 0-6 bulan & 550 & 0,5 \\
7-12 bulan & 650 & 7 \\
1-3 tahun & 1000 & 8 \\
4-6 tahun & 1550 & 9 \\
7-9 tahun & 1800 & 10 \\
\hline
\end{tabular}

*Berdasarkan Widya Karya Pangan RI 2004

per saji (2-3 keping) untuk biskuit. Jumlah kalori per saji MPASI bubur dan tim antara 160-210 kalori, sedangkan jumlah kalori per saji MPASI biskuit antara 80-90 kalori.

\section{Pembahasan}

Risiko terjadi anemia defisiensi besi pada masa bayi sangat tinggi, karena hanya kurang dari 50\% kebutuhan zat besi dapat dipenuhi oleh ASI setelah usia 6 bulan. Oleh karena itu kekurangan tersebut haruslah didapatkan dari sumber lain, yaitu dari makanan pendamping ASI yang mengandung cukup zat besi. ${ }^{5}$ Makanan pendamping ASI yang terdapat di pasaran mempunyai kandungan zat besi berkisar antara 0,48 hingga 4,8 mg atau memenuhi sekitar 6\%-60\% dari AKG untuk zat besi sesuai dengan usia mulai dari 6 bulan. Berdasarkan Tabel 2 dapat dilihat bahwa kebutuhan zat besi sejak usia 6 bulan melonjak dari 0,5 $\mathrm{mg} /$ hari menjadi $7 \mathrm{mg} /$ hari karena cadangan zat besi dari ibu sewaktu lahir sudah tidak lagi dapat memenuhi kebutuhan yang makin meningkat. ${ }^{8}$ Sampai dengan usia 6 bulan ASI masih mampu menyediakan zat gizi yang terbaik untuk bayi, tetapi kandungan zat besinya sangat jauh dari kecukupan yang dibutuhkan. ${ }^{5,8}$ Jika dihitung berdasarkan data yang tertera pada Tabel 1 dan 2, kekurangan tersebut dapat tercukupi dengan minimal pemberian 1-2 kali MPASI siap saji.

Seiring dengan kebutuhan yang meningkat dan peningkatan kemampuan ketrampilan makan bayi (jumlah, volume) maka MPASI dapat ditingkatkan menjadi 3-4 kali per hari sesuai pertambahan usia. ${ }^{5}$ Pada bayi yang tidak mendapat ASI, juga berlaku hal yang sama karena berdasarkan aturan Codex Alimentarius 1 liter susu formula bayi mengandung sekitar $6,7 \mathrm{mg}$ zat besi $(1 \mathrm{mg} / 100 \mathrm{kal})$ sehingga tetap memerlukan MPASI dengan kandungan zat besi yang harus mencukupi kebutuhan. ${ }^{9}$
Makanan pendamping ASI dalam bentuk biskuit mempunyai jumlah kandungan zat besi yang lebih sedikit per takar sajinya. Demikian pula dengan jumlah kalori per takar sajinya, jika dibandingkan dengan MPASI jenis bubur dan tim. Apalagi pada semua produk MPASI biskut tersebut dicantumkan saran penyajian yang menjadikannya sebagai bubur jika dilarutkan dengan air/susu formula/ASI. Hal tersebut perlu menjadi perhatian bagi dokter dan tenaga kesehatan sebagai pemberi informasi serta ibu/ pengasuh sebagai pelaksana pemberian makan bagi bayi. Masalah lain yang juga harus diperhatikan adalah takaran dan teknik penyajian yang sering tidak dipatuhi oleh ibu sehingga tidak tercapai jumlah dan nilai gizi sesuai dengan yang seharusnya.

Memang, Codex Alimentarius tidak mengatur secara rinci jumlah kandungan zat besi dalam MPASI berbasis sereal. Codex lebih banyak memberikan patokan terhadap makronutrien dan densitas kalori yang harus dipenuhi untuk MPASI (tidak boleh kurang dari $0,8 \mathrm{kal} / \mathrm{g}$ ) karena yang lain mengacu pada aturan penambahan vitamin dan mineral untuk bayi dan anak. ${ }^{6,7}$ Tetapi berdasarkan survei yang kami lakukan dapat diambil kesimpulan bahwa MPASI siap saji yang terdapat di pasaran mengandung zat besi yang bervariasi. Makanan pendamping ASI dalam bentuk bubur atau tim mengandung zat besi yang lebih tinggi dibanding dengan MPASI biskuit. Kandungan zat besi MPASI terendah adalah 0,48 mg per saji atau hanya mencakup 6\% AKG, sedangkan yang tertinggi $4,8 \mathrm{mg}(60 \% \mathrm{AKG})$ per sajinya. Disarankan untuk memperhatikan kandungan zat besi juga kalori per saji dan cara/saran penyajian agar didapatkan nilai dan kandungan gizi yang sesuai dengan yang tercantum dalam informasi nilai gizi pada label produk.

\section{Daftar pustaka}

1. Anderson JJB. Minerals. Dalam: Mahan KL, EscottStump S, penyunting. Krause's food, nutrition and diet therapy. Edisi ke-11. Philadelphia: Saunders;2000.h.120-58.

2. World Health Organization/United Nations University/UNICEF. Iron deficiency anaemia, assessment, prevention and control: a guide for programme managers. Geneva: World Health Organization, 2001. 
3. Lozoff B, De Andraca I, Castillo M, Smith JB, Walter T, Pino P. Behavioral and developmental effects of preventing iron-deficiency anemia in healthy fullterm infants. Pediatrics 2003;112:846-54.

4. Shafir T, Angulo-Barroso R., Jing Y, Angelilli ML, Jacobson SW, Lozoff B. Iron deficiency and infant motor development. Early Hum Dev 2008;84:479-85.

5. World Health Organization. Infant and young child feeding: model chapter for textbooks for medical students and allied health professionals. Geneva: World Health Organization, 2009.

6. Codex standard for processed cereal-based foods for infants and young children (Codex Stan 074-1981, Rev.1-2006) Diunduh dari: http:// www.codexalimentarius.net/download/standards/300/ CXs_074e.pdf diakses pada 10 Mei 2011.

7. Advisory lists of mineral salts and vitamin compounds for use in foods for infants and children (CAC/GL 10-1979). Diunduh dari: http:// www.codexalimentarius.net/download/standards/300/ CXG_010e.pdf diakses pada tanggal 1 Juni 2011.

8. Angka kecukupan gizi 2004. Diunduh dari: http:// www.gizi.net/lain/gklinis/AKG2004.htm diakses pada tanggal 20 April 2011.

9. Standard for infant and formula for special medical purposes intended for infants (Codex Stan 72-1981, Rev-2006). Diunduh dari http://www.codexalimentarius. net/download/standards/288/CXS_072e.pdfdiakses pada tanggal 21 Januari 2011. 